\title{
A situational analysis of the current level of lecturers' engagement with internationalisation of the curriculum in Ireland's first Technological University
}

\author{
Deirdre Ryan \\ deirdre.ryan@tudublin.ie \\ Fiona Faulkner \\ Technological University Dublin, fiona.faulkner@tudublin.ie \\ Dominic Dillane \\ Technological University Dublin, dominic.dillane@tudublin.ie
}

See next page for additional authors

Follow this and additional works at: https://arrow.tudublin.ie/ltcart

Part of the Higher Education Commons

\section{Recommended Citation}

Deirdre Ryan, Fiona Faulkner, Dominic Dillane \& Robert V. Flood (2020) A situational analysis of the current level of lecturers' engagement with internationalisation of the curriculum in Ireland's first Technological University, Irish Educational Studies, 39:1, 101-125, DOI: 10.1080/03323315.2019.1663551

This Article is brought to you for free and open access by the Learning Teaching \& Assessment at ARROW@TU Dublin. It has been accepted for inclusion in Articles by an authorized administrator of ARROW@TU Dublin. For more information, please contact arrow.admin@tudublin.ie, aisling.coyne@tudublin.ie, gerard.connolly@tudublin.ie.

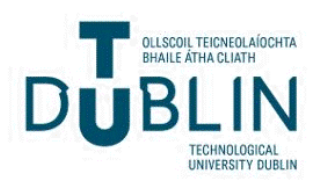




\section{Authors}

Deirdre Ryan, Fiona Faulkner, Dominic Dillane, and Robert Flood

This article is available at ARROW@TU Dublin: https://arrow.tudublin.ie/ltcart/83 
See discussions, stats, and author profiles for this publication at: https://www.researchgate.net/publication/335897535

\section{A situational analysis of the current level of lecturers' engagement with internationalisation of the curriculum in Ireland's first Technological University}

Article in Irish Educational Studies · September 2019

DOI: 10.1080/03323315.2019.1663551

CITATIONS

3

4 authors:

Q Deirdre Ryan

Technological University Dublin - City Campus 4 PUBlications 5 Citations

SEE PROFILE

Dominic Dillane

Technological University Dublin - City Campus

2 PUBLICATIONS 4 CITATIONS

SEE PROFILE

Some of the authors of this publication are also working on these related projects:
READS

142

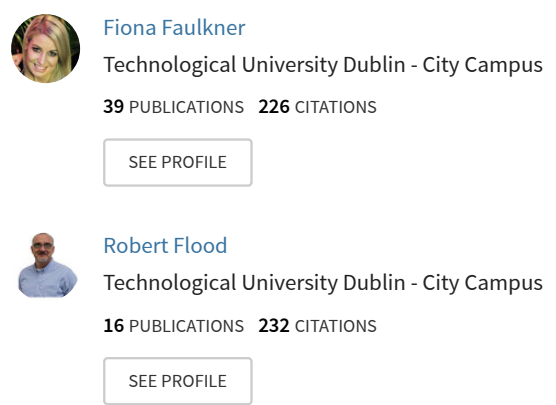

Project Photofragmentation studies by mass resolved REMPI. View project

Project Examination of Progression rates of international students on a foundation programme View project 


\title{
A situational analysis of the current level of lecturers' engagement with internationalisation of the curriculum in Ireland's first Technological University
}

\author{
Deirdre Ryan, Fiona Faulkner, Dominic Dillane \& Robert V. Flood
}

To cite this article: Deirdre Ryan, Fiona Faulkner, Dominic Dillane \& Robert V. Flood (2019): A situational analysis of the current level of lecturers' engagement with internationalisation of the curriculum in Ireland's first Technological University, Irish Educational Studies, DOI: 10.1080/03323315.2019.1663551

To link to this article: https://doi.org/10.1080/03323315.2019.1663551

+ View supplementary material 단

曲 Published online: 18 Sep 2019.

Submit your article to this journal $\pi$

Щ Article views: 31

Q View related articles $\sqsubset$

View Crossmark data $[\pi$ 


\title{
REVIEW
}

\section{A situational analysis of the current level of lecturers' engagement with internationalisation of the curriculum in Ireland's first Technological University}

\author{
Deirdre Ryan*, Fiona Faulkner, Dominic Dillane and Robert V. Flood \\ Technological University, Dublin, Ireland
}

(Received 6 September 2018; accepted 14 August 2019)

\begin{abstract}
The educational value of internationalisation in higher education is of critical importance for both domestic and international students. While national and institutional policies globally are increasingly prioritising internationalisation, the resultant consequences for the teaching and learning context are not adequately being explored. Understanding engagement with Internationalisation of the Curriculum from the lecturers' perspective allows for a greater insight into the inherent implementation gap between the theory and practice of the process. This knowledge may then help inform strategies to address the gap. The present study details the current level of engagement between lecturers and Internationalisation of the Curriculum in Ireland's first Technological University. A questionnaire was designed and distributed to all lecturers across the university to ascertain statistical evidence in an attempt to quantify the prevailing situation in the Irish higher education context. While there was an awareness and appreciation of the educational value of internationalisation, the findings demonstrate that those surveyed are at the early stages of the internationalisation process in their teaching and learning practice. The questionnaire findings are detailed here along with the implications of the findings for both internationalisation and educational policies and practice, which is of relevance to both national and international audiences.
\end{abstract}

Keywords: internationalisation of higher education; internationalisation of the curriculum; situational analysis; lecturers' engagement; policy and practice

\section{Introduction}

Internationalisation in the higher education context has been a topic of discussion and prevalent in research for many years due to its associated cultural, educational and economic benefits (Ireland's International Education Strategy 2010). While there is extensive literature on the topic of internationalisation of higher education and the associated educational benefits, there is limited research that focusses on the practical means of effective implementation (Clifford and Montgomery 2011; Leask 2011, 2013; Whitsed and Green 2016). More specifically there is very little research in the Irish higher education context as Ireland is still in a relatively early stage of the internationalisation process focussing particularly on student recruitment and the associated activities. It is also at an earlier development stage of

\footnotetext{
*Corresponding author. Email: deirdre.ryan@tudublin.ie 
engagement with Internationalisation of the Curriculum (IoC) (Clarke, Yang, and Harmon 2018).

In May 2018, the Higher Education Authority (HEA) in Ireland produced a landmark report titled 'The Internationalisation of Irish Higher Education' which was the first study of this kind in Irish higher education. The report addresses internationalisation from a variety of perspectives and articulates the need for Irish HEIs to further consider and explore the concept and practice of IoC (Clarke, Yang, and Harmon 2018). The objective of this paper is to address the implementation gap between theory and practice of internationalisation in the higher education context, which has relevance both nationally and internationally. Definitions, benefits and the current status of internationalisation in the Irish higher education context are considered. Initial findings and analysis of an IoC questionnaire which was distributed to lecturers in three Irish Institutes of Technology (Dublin Institute of Technology, Institute of Technology Tallaght and Institute of Technology Blanchardstown) that have recently merged to become Technological University Dublin (TU Dublin) are discussed and their implications for both internationalisation and Teaching and Learning $(T \& L)$ policies and practice are outlined.

\section{What is internationalisation of higher education?}

De Wit et al.'s (2015) definition captures the on-going and comprehensive nature of internationalisation of higher education. They describe it as:

the intentional process of integrating an international, intercultural or global dimension into the purpose, functions or delivery of postsecondary education, in order to enhance the quality of education and research for all students and staff, and to make a meaningful contribution to society (De Wit et al. 2015, 281).

Furthermore Hudzik (2015a) describes four key aspects of adopting a comprehensive approach, namely,

(1) It is a mainstream process insofar as it is all encompassing and relates to all staff and students.

(2) It integrates comprehensive internationalisation into core institutional missions; it is not an additional mission.

(3) It expands the support and contribution to internationalisation; it is not just the responsibility of the international office and requires active engagement from all key stakeholders.

(4) It is interconnected and seeks synergies across teaching, research and service missions of the HEI (Hudzik 2015b).

The concepts of Internationalisation at Home ( $\mathrm{IaH})$ and Internationalisation of the Curriculum (IoC) are inherent components of comprehensive internationalisation and shift the focus from the economic to educational benefits (Beelen and Jones 2015; Hudzik and McCarthy 2012). They are defined as follows:

Internationalisation of the Curriculum is the incorporation of an international and intercultural dimension into the content of the curriculum as well as the teaching, learning and 
assessment arrangements and support services of a programme of study (Leask 2009, 209).

Internationalisation at Home is the purposeful integration of international and intercultural dimensions into the formal and informal curriculum for all students, within domestic learning environments (Beelen and Jones 2015, 76).

Here the concepts of IoC and $\mathrm{IaH}$ are merged and referred to solely as IoC, which highlights the relevance of $\mathrm{IoC}$ to all students both domestic and international. It also captures the comprehensive nature of $\mathrm{IoC}$ which relates to the overall mission of HEIs to enhance T\&L.

\section{Benefits of internationalisation of higher education}

\section{Economic benefits}

The economic benefits of internationalisation of higher education are widely discussed in the literature from both an institution specific and whole economy perspective (Hegarty 2014; Bergerhoff et al. 2013; Universities UK 2014). At institution level, the international student recruitment is an important alternative source of revenue which is used for financing teaching, research, resources and support services (Hawanini 2011; Leask 2015).

The benefits to the economy as a whole are significant as the impact stretches beyond tuition fees and includes accommodation, spending off campus and other expenditure (Universities UK 2014).

\section{Educational benefits}

The educational benefits can largely be categorised under the following two broad headings.

(1) Improved quality of Teaching and Learning

(2) Increased international awareness (De Wit et al. 2015)

\section{Improved quality of teaching and learning}

Internationalisation inspires innovations in T\&L by responding to the cultural diversity that is a reality of contemporary education (De Wit 2010; Leask 2011, 2015; Kreber 2009; Svensson and Wihlborg 2010). In turn it results in a more meaningful and purposeful education for the whole student cohort. Through adding international and intercultural dimensions to the teaching and learning content, pedagogy and assessment, the curriculum becomes more inclusive for international students. Simultaneously it better prepares all students, international and domestic, to live and work ethically and competently in the global world (Jones 2010; De Wit et al. 2015). When the focus is on IoC, the cultural diversity that exists in the classrooms is leveraged upon and the T\&L environment is more reflective of the global workplace students will be graduating into (Hellsten 2007). Similarly IoC will potentially lead to more inclusive and globally relevant curricula for all students with an improved outlook on graduate employability (De Wit et al. 2015; Jones 2010). It has the potential to improve the student experience and facilitates the development of cross-cultural friendships and breaks down potential barriers that can exist due to cultural and linguistic differences. 
Internationalised curricula are also linked to improved university rankings (HEA 2012; Henard, Diamond, and Roseveare 2012).

\section{Increased international awareness}

The 4th International Association of Universities (IAU) survey regards student knowledge of and appreciation of international issues as the most significant benefit of IoC (Egron-Polak and Hudson 2014). The global world and workplace that today's students are graduating into demands internationally oriented thinking and understanding (Coelen 2015; Hawanini 2011; Henard, Diamond, and Roseveare 2012). As knowledge economies and societies expand their horizons to global dimensions, so too should the education system that is integral to its success. Global citizenship and the associated intercultural competencies are sought after attributes of twenty-first century graduates. IoC fosters a greater appreciation and understanding of international events, perspectives and methods, all of which prepare students for the modern world (Henard, Diamond, and Roseveare 2012; Murphy, cited in Kreber 2009).

\section{Internationalisation in the Irish higher education context}

Both the 2010 and 2016 Government strategies (Department of Education and Skills 2010, 2016) for internationalisation of higher education stipulate the objective for Irish HEIs to be globally competitive, internationally oriented and world class centres of international education. The National Strategy for Higher Education to 2030 in Ireland (universally known as the Hunt Report) also states the need for HEIs to prioritise internationalisation (Hunt Report 2011). Limited research has been conducted to date regarding Irish HEI's approach to comprehensive or campus-wide internationalisation. The existing studies, however, do document the need to view internationalisation as an educational resource and to take a more integrated approach. Some studies have looked at international students' satisfaction levels (Finn and Darmody 2017) and others at the associated challenges from the students' and lecturers' perspective.

\section{Challenges from students' perspective}

Dunne (2009) conducted research in Dublin City University which focussed on domestic students' perspectives of intercultural contact in Irish HEIs. This study highlighted the importance of facilitating cross-cultural interactions through T\&L delivery. The mere presence of international students does not result in an international campus. Students felt that the institution did not adequately support intercultural communication. Clarke et al.'s study (2018) also commented on the divide between international and domestic students in Irish HEIs. Emphasising the importance of IoC amongst lecturing staff and supporting them in this regard would help foster a culture of integration as it would raise awareness of the cultural diversity that exists in the contemporary classroom.

\section{Challenges from lecturers' perspective}

University College Dublin conducted a small study which reported on challenges from the lecturers' perspectives related to cultural issues and a lack of interest in the topic of internationalisation of higher education (O’ Reilly, Hickey, and Ryan 2013). The 
perceived lack of support can lead to poor engagement with internationalisation activities and is further hindered by a lack of policy and procedure documents which would support successful implementation of internationalisation in the T\&L environment. They reported the need for institutions to be more engaged and aware of international students as a whole and furthermore the need to reconceptualise internationalisation to acknowledge the two way process and the relevance to both domestic and international students (O' Reilly, Hickey, and Ryan 2013). This relates to the bigger picture of the institution's stance on diversity. Similarly Coate's study (2013) acknowledges the need for HEIs to recognise the changing student cohort and to approach internationalisation of higher education in a more ethical fashion. This study aims to expand on the research in the Irish context by ascertaining the current level of engagement, understanding and conceptualisation of IoC from lecturers in TU Dublin.

\section{This study}

The study was conducted in TU Dublin. Table 1 summarises the profile of TU Dublin from a range of available metrics. The data demonstrates the scale of the university, the range of disciplines offered and for the purpose of this study, the stage of internationalisation in terms of student mobility. While the internationalisation strategies of the individual Institutes of Technology prior to the merger almost exclusively focussed on student recruitment and staff and student mobility, the TU Dublin internationalisation strategy adopted the comprehensive approach as per best practice in the literature (Hudzik 2015b; Leask 2009). This approach ensures internationalisation is

Table 1. Technological University Dublin Institutional Profile (HEA 2016).

Technological University Dublin

Year established 2019

Total number of students $\quad 28,153(19,137$ full-time and 9016

First Year Full Time Undergraduate New Entrants by $\begin{gathered}\text { part-time) } \\ \text { |Business, Administration \& Law- }\end{gathered}$ Discipline (top 5 disciplines) 1167

Engineering, Manufacturing \& Construction- 999

Arts \& Humanities- 728

Information \& Communication

Technology -499

Natural Sciences, Maths \&

Statistics- 405

Total number of undergraduate students (level $\mathbf{7 \& 8}$, full \& $\quad 19,076$ part-time)

Total number of postgraduate student (level 9 Master's 2011 taught \& research, full \& part-time)

Total number of doctoral students

Total number of full- time non-EU International students 1086

Total number of full-time EU international students $\quad 185$

Total number of academic staff 1364

Total number of support staff 1070 
embedded in all university activities so that it can contribute to the quality of the education being provided. Both IoC and $\mathrm{IaH}$ are key features of the strategy. Furthermore the TU Dublin internationalisation strategy aims to support and complement the TU curriculum model and associated T\&L enhancement agenda which stipulates that its key endeavours are teaching, learning, research and engagement in a global context. It also aims to inform and fundamentally improve TU Dublin's educational practice on an ongoing basis). TU Dublin promotes a student-centred and multi-cultural approach to learning, both of which are the essence of IoC. One of the distinguishing features of the TU is that it aims be a globally engaged university. Furthermore one of the key criteria for achieving TU status was for the institution to demonstrate a developmental trajectory of how it plans to address internationalisation in the T\&L environment (HEA 2012). The first step in this process was to conduct a situational analysis of the current level of understanding, awareness and engagement with IoC amongst lecturers in TU Dublin. This would provide an insight to the current state of IoC affairs and possibly highlight some steps that need to be taken in order to foster a culture of support for IoC amongst lecturers. This was the rationale for conducting the IoC questionnaire with lecturers from across TU Dublin.

The following research questions guided the study.

(1) To what extent do lecturers understand and engage with the concept of Internationalisation of the Curriculum?

(2) If lecturers are not engaging with Internationalisation of the Curriculum, why is this the case in spite of an increasing presence of internationalisation in Government, HEI and HEA policy documents and an increasing number of Internationalisation of the Curriculum guides?

\section{Methodology}

A questionnaire was used to obtain statistical information to quantify and better understand the prevailing situation regarding internationalisation in the T\&L environment in TU Dublin. This would also help with further understanding of the noted implementation gap between theory and practice surrounding IoC. Full ethical approval was received from the TU Dublin, Graduate Research Ethical Committee in advance of this study.

\section{Questionnaire: design and considerations}

The first priority when designing the questionnaire was to address the research questions. The second priority was to consider the Irish higher education environment and more specifically the TU context to ensure the questionnaire devised was relevant to the overall TU goals. This involved addressing the internationalisation aspects of the following policy documents throughout the questionnaire:

(1) HEA criteria for TU designation

(2) National Strategy for Higher Education - The Hunt Report

(3) National Strategy for Internationalisation of Higher Education (2010-2016)

(4) Typology of internationalisation activities from the TU for Dublin implementation plan 
The third priority was to consider existing mapping and benchmarking tools for internationalisation of higher education from an international context. The key tools deemed most relevant to inform this research were as follows:

- The McKinnon Internationalisation Benchmarking Guide (McKinnon, Walker, and Davis 2000)

- Indicator for Mapping and Profiling Internationalisation (IMPI) (EP-Nuffic, 2009-2012)

- American Council of Education (ACE) Mapping Internationalisation Survey (ACE 2012)

- Mapping Internationalisation (MINT) (EP-Nuffic 2008)

- International Association of Universities (IAU) 4th Global Survey (EgronPolak and Hudson 2014)

- Questionnaire on the Internationalisation of the Curriculum (QIC) (Leask 2011)

- EAIE Barometer Survey (2014)

Finally, careful consideration was given to question style and layout in order to maximise the reliability and validity of the responses (Fowler 2014). The questionnaire had two main sections. The first section aimed to collect demographic information which afforded the opportunity to identify relationships between lecturers' professional context and engagement with IoC. The second section was to gather information to ascertain the current level of understanding, awareness and engagement, if any, with IoC. The majority of questions were close-ended and required the use of the Likert scale. A small number of open-ended questions were also included to capture more closely the actual views of the respondents and to add variety (Fowler 2014). As a result the following variables and indicators were identified (see Table 2). The associated questions are marked in the table and the final questionnaire, developed based on all previously outlined considerations and best practice in questionnaire design methodology, can be found at Appendix A.

\section{Questionnaire distribution}

The questionnaire was initially piloted with a small team of lecturers. Any mistakes that were identified were corrected and questionnaire items were refined based on the feedback. It also provided a useful indication of the length of time the questionnaire takes (Cohen, Manion, and Morrsion 2007; Fowler 2014). The finalised questionnaire, which had 26 questions (see Appendix A), was then distributed to all lecturers across TU Dublin. In order to maximise the response rate, a mixed mode data collection was employed by distributing both online and paper-based versions of the questionnaire. This also ensured a more representative sample was collected as solely doing a self-selecting online survey could skew results as it could potentially only attract those who have a basic interest or familiarity with the topic. This also reduced self-selection bias (Bethlehem 2008). Paper-based questionnaires were distributed at school meetings across the university, but due to time conflicts it was only possible to attend some meetings and hence the online questionnaire was also required. 
Table 2. Questionnaire variables and associated indicators which informed the final questions.

Variable Related indicators

Understanding of IoC (questions 1, 2, 3, 4, $10,11,22,23)$

Support for IoC (questions 5, 6, 7, 8, 9, 25, 26)

Engagement with IoC (questions 12, 13, $14,15,16,17,18,19,24)$

Openness to further engagement with IoC (question 24)

Obstacles for engagement with IoC (questions 20, 23)

Enablers for engagement with IoC (questions 21, 22, 26).
- Awareness of concept of internationalisation of higher education

- Awareness of institute's existing internationalisation strategy

- Awareness of concept of IoC

- Responsibility for internationalisation at school/programme level

- Drivers of IoC

- Related professional development opportunities

- Conferences

- Professional development

- Action research

- Communities of Practice

- Engagement with international industries/ professional associations

- Internationally focussed learning outcomes

- Internationally focussed learning activities

- Internationally focussed assessments

- Graduate attributes/ Global citizenship

- Intercultural competence

- Interest in related professional development

- Funding

- Policies \& procedures

- Professional development

- T\&L commitments

- Senior leadership support

- Understanding of concept

- Rewards/recognition

- As above

\section{Response rate}

The questionnaire was distributed to all lecturers $(n=856)$ across TU Dublin. A total of 196 completed questionnaires were received, the study therefore had a response rate of $16 \%$.

\section{Data analysis}

Statistical analysis was conducted using the statistical software package IBM SPSS Statistics for Windows (Version 24) whereby numerical data about IoC was collected to explain the phenomenon of lecturers' engagement with IoC, or lack thereof. Table 3 summarises the categorical data from the questionnaire, more specifically the demographic profile of the respondents.

Quantitative analysis is useful to quantify lecturers' opinions, attitudes and behaviours relating to IoC to ascertain how this particular population feels about the topic 
Table 3. Demographic profile of lecturers who responded to the questionnaire.

\begin{tabular}{llll}
\hline Age & \multicolumn{1}{c}{ Gender } & \multicolumn{1}{c}{ Years Teaching } & \multicolumn{1}{c}{ Discipline } \\
\hline $25-34: 8.2 \%$ & $49.5 \%$ Female & $0-1: 6.1 \%$ & Arts \& Humanities: \\
$35-44: 34.2 \%$ & $49.0 \%$ Male & $2-4: 13.8 \%$ & $23.5 \%$ \\
$45-54: 34.7 \%$ & $(1.5 \%$ value & $5-7: 7.1 \%$ & Business: $20.4 \%$ \\
$55-64: 20.9 \%$ & missing $)$ & $7-9: 6.1 \%$ & Engineering: $17.3 \%$ \\
$65+: .5 \%(1.5 \%$ value & & $10+: 66.3 \%$ & Science: $27.6 \%$ \\
missing) & & $(.5 \%$ value missing $)$ & Other: $10.7 \%$ \\
\hline
\end{tabular}

(Cresswell 2003). Descriptive statistics were generated relating to frequency counts of the open-ended responses. Anova and t-tests were also carried out in order to generate inferential statistics. Both the descriptive and the inferential statistics provided a snapshot of the current status and allowed for an exploration of the relationships, if any, between variables. The level of significance used for all tests was $5 \%$ and no adjustments were made for multiple testing.

Responses to the open-ended questions were coded for meaning, feelings, actions and events (Cohen, Manion, and Morrsion 2007), these codes were subsequently categorised as themes. A number of major themes emerged and frequency counts were then conducted to outline the most commonly occurring themes. Based on the literature on IoC and the researcher's own observations of lecturers' engagement and understanding of IoC, the hypothesis is that there is little understanding, awareness or engagement with IoC in the T\&L environment of TU Dublin.

\section{Findings}

In order to address the research questions, the questionnaire was organised into categories relating to lecturers' understanding of internationalisation of higher education and $\mathrm{IoC}$, and their engagement with IoC. Table 4 shows the breakdown of questions per category and the associated findings are then discussed.

\section{Understanding of internationalisation of higher education and internationalisation of the curriculum}

Examining the questionnaire responses to questions related to lecturers' understanding of internationalisation of higher education and IoC, provided useful insights into the first research question, which is:

Table 4. Categorisation of questionnaire questions according to research questions.

\begin{tabular}{lc}
\hline Category & Related Questions \\
\hline $\begin{array}{l}\text { Lecturers' Understanding of internationalisation of } \\
\text { higher education and IoC }\end{array}$ & Questions: 1,2,3,4,5, 6, 11,20, 22 and 23 \\
Lecturers' Engagement with IoC & Questions: 7, 8, 9, 10, 12, 13, 14, 15, \\
& $16,17,18,19,21$ and 24 \\
\hline
\end{tabular}


Table 5. Categories of comments made by lecturers in relation to their understanding of internationalisation of higher education.

\begin{tabular}{lccc}
\hline $\begin{array}{l}\text { Categories of } \\
\text { comments }\end{array}$ & $\begin{array}{c}\text { Frequency of } \\
\text { comments }\end{array}$ & $\begin{array}{c}\text { Percentage of } \\
548 \text { comments }\end{array}$ & Sample comments \\
\hline Culture \& Diversity & 72 & $13 \%$ & " multi-cultural experiences", \\
"working in cross-cultural groups", \\
"intercultural" " diversity" \\
$\begin{array}{l}\text { Erasmus- Student } \\
\text { \& Teachers }\end{array}$ & 57 & $10 \%$ & $\begin{array}{c}\text { "mobility", "erasmus", "exchange } \\
\text { programmes" }\end{array}$ \\
$\begin{array}{l}\text { Global } \\
\text { Finance }\end{array}$ & 51 & $9 \%$ & $\begin{array}{c}\text { "Globalisation", "China", "Europe" } \\
\text { "more income", "fees", "money" }\end{array}$ \\
Foreign & 27 & $5 \%$ & $\begin{array}{c}\text { "non-national students", "international } \\
\text { students" }\end{array}$ \\
\hline
\end{tabular}

(1) To what extent do lecturers understand and engage with the concept of Internationalisation of the Curriculum?

The questionnaire responses shed light on lecturers':

- conceptualisation of internationalisation of higher education

- conceptualisation of IoC

- perceived barriers to understanding and engaging with IoC

- perceived facilitating factors to understanding and engaging with IoC

- perceptions of senior leadership support

\section{Conceptualisation of internationalisation of higher education}

Lecturers were asked to indicate their level of familiarity with internationalisation of higher education. Table 5 summarises the leading five themes that emerged when lecturers were asked to share the top three words they associate with internationalisation of higher education (question 1). In total 548 comments were made in response this question. The responses were categorised after a process of coding and subsequent identification of themes, as outlined in the data analysis section. The frequency values and sample comments of the key words predominantly used that illustrate the common views held by lecturers are also included in the table.

In terms of lecturers' understanding of internationalisation of higher education, the most common theme that emerged was 'culture and diversity' which accounted for $13 \%$ of the responses (see Table 5). The other dominant themes related to both the economic benefits of internationalisation $(5 \%)$ and the mobility aspect $(10 \%)$ of the process. Themes relating to globalisation $(9 \%)$ and international students in general (4\%) also featured quite regularly. Only $2 \%$ of respondents associated internationalisation of higher education with the curriculum.

\section{Conceptualisation of internationalisation of the curriculum}

Lecturers were specifically asked about their understanding of IoC (question 3). Their responses can be seen in Table 6 . Coding of the 525 responses gave rise to five main categories which are outlined in the table. 
Table 6. Categories of comments made by lecturers in response to their understanding of Internationalisation of the Curriculum.

\begin{tabular}{|c|c|c|c|}
\hline $\begin{array}{l}\text { Categories of } \\
\text { comments }\end{array}$ & $\begin{array}{l}\text { Frequency of } \\
\text { comments }\end{array}$ & $\begin{array}{l}\text { Percentage of } \\
525 \text { comments }\end{array}$ & Sample comments \\
\hline Learning & 67 & $13 \%$ & $\begin{array}{l}\text { "improvement of module content", } \\
\text { "internationalised assessment", } \\
\text { "international examples" }\end{array}$ \\
\hline $\begin{array}{l}\text { Negative } \\
\text { Connotations }\end{array}$ & 59 & $11 \%$ & $\begin{array}{l}\text { "challenging", "unrealistic", } \\
\text { "hegemony", "difficult", } \\
\text { "unsupported", "ad hoc", } \\
\text { "superficial” }\end{array}$ \\
\hline $\begin{array}{l}\text { Positive } \\
\text { Connotations }\end{array}$ & 54 & $10 \%$ & $\begin{array}{l}\text { "essential", "imperative", } \\
\text { "opportunities", "interesting", } \\
\text { "desirable" }\end{array}$ \\
\hline Language & 50 & $9 \%$ & $\begin{array}{l}\text { "language barriers", " language } \\
\text { challenges" }\end{array}$ \\
\hline Inclusive & 45 & $9 \%$ & $\begin{array}{l}\text { "broader perspectives", "universality", } \\
\text { "understanding" }\end{array}$ \\
\hline
\end{tabular}

The most common theme arising, when lectures were asked to list the first three words they think of when they consider IoC in their T\&L practice, related to the impact of internationalisation on T\&L. A large proportion of the responses $(13 \%)$ related to $T \& L$ activities that address internationalisation e.g. including international case studies, examples \& global perspectives, adding international related learning outcomes to module descriptors, engaging in problem based learning. The other key themes were categorised as either positive $(10 \%)$ or negative $(11 \%)$ connotations associated with IoC, with marginally more negative associations. The negative comments related predominately to challenges $(22 \%)$, lack of support $(24 \%)$ and the perceived lack of relevance of IoC (27\%). The lack of knowledge of IoC on the part of some respondents could be attributed to the fact that the majority of respondents were only slightly familiar $(31 \%)$ or not at all familiar $(26 \%)$ with their institute's internationalisation strategy (question 2). Furthermore less than one in ten stated they were extremely familiar with the strategy. Similarly the majority were either slightly familiar $(30 \%)$ or not at all familiar $(24 \%)$ with the standard definition of IoC (question 4$)$ and didn't feel it was a priority in their institutes. $26 \%$ felt it was a low priority, $12 \%$ felt it was not a priority and $12 \%$ did not have an opinion (question 5).

\section{Perceived barriers of internationalisation of the curriculum}

Lecturers were asked to indicate the key deterrents of engaging with IoC (question 23). The responses further exemplify some of the lecturers' negative perceptions of IoC. Table 7 summarises the responses.

The most frequently cited deterrent for lecturers to internationalise their curricula was time constraints. Comments predominantly expressed the lack of time due to pressure to complete other teaching goals, competing priorities and busy workload. Other themes to emerge from the questionnaire were concerns about lack of 
Table 7. Categories of comments made by lecturers in relation to key perceived deterrents to Internationalisation of the Curriculum.

\begin{tabular}{lccc}
\hline $\begin{array}{l}\text { Category of } \\
\text { comments }\end{array}$ & $\begin{array}{c}\text { Frequency of } \\
\text { comments }\end{array}$ & $\begin{array}{c}\text { Percentage of } \\
410 \text { comments }\end{array}$ & \multicolumn{1}{c}{ Sample comments } \\
\hline Time & 101 & $25 \%$ & $\begin{array}{c}\text { "not enough time to develop lecture } \\
\text { material because of heavy teaching } \\
\text { workload", "competing demands to } \\
\text { cover learning objectives of the } \\
\text { module", "time-consuming } \\
\text { particularly at the start", "too many } \\
\text { priorities" } \\
\text { "lack of clarity on school policy, } \\
\text { direction", "lack of support to staff \& } \\
\text { students", "lack of awareness of } \\
\text { benefits", "lack of expertise \& } \\
\text { direction" }\end{array}$ \\
\hline 95 & $23 \%$ & \\
& &
\end{tabular}

funding (5\%) and also about T\&L related issues (10\%). Of the T\&L issues $40 \%$ mentioned challenges associated with engaging students with IoC activities and 50\% mentioned the challenge of adopting the existing curricula to add an international dimension. Furthermore lecturers were asked to choose the most common obstacles that they feel impacted on their incorporation of IoC (question 20). 'Competing T\&L priorities' ranked highest being mentioned in 58\% of responses and 'Lack of understanding of what is involved at a practical level' was rated as the next biggest obstacle which was mentioned in $48 \%$ of responses.

\section{Perceived facilitating factors to engage with internationalisation of the curriculum}

While some negative comments were apparent, there were also a range of responses that had positive connotations. Many responses demonstrated lecturers' appreciation of the opportunities and value associated with IoC. Lecturers were asked to exemplify the most compelling reasons to internationalise their curriculum (question 11). When the responses were coded the majority fell into three categories which are summarised in Table 8. Their choice of vocabulary denotes their understanding of the importance and relevance of engaging with $\mathrm{IoC}$ for both international and domestic students, and associated quality implications. Some examples of this can be seen in the sample comments column.

The majority of lecturers referenced the importance of equipping students with skills for the global workplace and the potential for IoC to improve the employability of graduates $(26 \%)$. Many lecturers also commented on the benefits of expanding students' knowledge and broadening their horizons to include international perspectives $(19 \%)$.

\section{Perceptions of senior leadership support}

Lecturers' were asked whether they felt senior leadership were active in their support of IoC. In terms of lecturers' understanding of senior leadership support of IoC 
Table 8. Categories of comments made by lecturers in relation to compelling reasons to internationalise the curriculum.

\begin{tabular}{lccc}
\hline $\begin{array}{l}\text { Category of } \\
\text { comments }\end{array}$ & $\begin{array}{c}\text { Frequency of } \\
\text { comments }\end{array}$ & $\begin{array}{c}\text { Percentage of } \\
181 \text { comments }\end{array}$ & Sample comments \\
\hline Employability & 47 & $26 \%$ & $\begin{array}{l}\text { "gives students greater skill sets for } \\
\text { foreign employment opportunities", } \\
\text { "exposure of students to global } \\
\text { software industry", "increases } \\
\text { employability" }\end{array}$ \\
$\begin{array}{l}\text { Expanded } \\
\text { Knowledge }\end{array}$ & 36 & $19 \%$ & $\begin{array}{l}\text { "keep current \& relevant", "provide } \\
\text { global outlook \& opportunities for } \\
\text { students in a modern curriculum", } \\
\text { "broaden the learning experience of } \\
\text { students" }\end{array}$ \\
Inclusivity & 17 & $9 \%$ & $\begin{array}{l}\text { "we are now a multicultural society", } \\
\text { "to reduce ethnocentrism } \\
\text { \&encourage students to adopt a more } \\
\text { global perspective" }\end{array}$ \\
\hline
\end{tabular}

initiatives (questions $6 \& 7$ ) while $19 \%$ of respondents perceived they were very active, the majority felt they were not very active (20\%), not active at all (18\%) and 22\% didn't know either way. Furthermore the majority of lecturers reported rarely $(39 \%)$ or never $(19 \%)$ receiving communication related to IoC.

\section{Engagement with internationalisation of the curriculum}

Responses to the questions specifically related to engagement with IoC revealed the following findings.

- Current engagement with IoC

- Factors that influenced engagement with IoC

\section{Current engagement with IoC}

Lecturers were questioned regarding their implementation of IoC into their module delivery (question 12) and the breakdown of responses is shown in Table 9.

The subsequent questions further examined these responses particularly regarding internationalising the T\&L content, T\&L strategies and assessment. It is concluded that the majority of lecturers felt they 'somewhat' engaged with internationalisation $(43 \%)$ and that their modules 'somewhat' prepared students for the global world (61\%). Approximately one-third of respondents seldom or never included IoC strategies in their teaching. Lecturers were asked to outline the strategies they currently utilise to internationalise their curriculum (question 19) and Table 10 outlines the breakdown of responses.

These percentages of lecturers who are incorporating strategies are high and suggest that lecturers are trying to incorporate international dimensions into their practice. Only $6 \%$ reported that they had accessed publically available IoC guides. 
Table 9. Lecturer responses on whether their modules include internationally focussed learning outcomes.

Question 12: Do any of your modules currently include internationally focussed learning outcomes? Response

Yes

$45.9 \%$

No

$45.4 \%$

Don't know

$8.2 \%$

\section{Factors that influenced engagement with IoC}

Lecturers were asked to specify the key items they felt influenced their incorporation of IoC (question 21). The vast majority felt their own international experiences influenced their engagement with IoC (52\%). Many also attributed their engagement to 'active links to international industries and professional associations' (45\%) and 'encouragement and support to attend international conferences' (38\%). Only 16\% stated that IoC related Continuous Professional Development (CPD) influenced their engagement and 10\% felt that the institutes international strategy had an impact on this.

\section{Quantitative findings}

A series of independent sample t-tests and one-way ANOVA tests were conducted to explore potential relationships between demographical data collected in part 1 of the

Table 10. Lecturer responses to the types of internationalisation of the curriculum strategies they incorporate into their T\&L.

\begin{tabular}{lcc}
\hline $\begin{array}{l}\text { Internationalisation of the curriculum } \\
\text { strategy }\end{array}$ & $\begin{array}{c}\text { Percentage who } \\
\text { responded 'yes' to } \\
\text { incorporating the strategy }\end{array}$ & $\begin{array}{c}\text { Percentage who } \\
\text { responded 'no' to } \\
\text { incorporating the strategy }\end{array}$ \\
\hline $\begin{array}{l}\text { Use comparative international } \\
\text { literature }\end{array}$ & $58 \%$ & $42 \%$ \\
$\begin{array}{l}\text { Integrate international \& cross- } \\
\text { cultural perspectives within teaching }\end{array}$ & $50.5 \%$ & $49.5 \%$ \\
$\begin{array}{l}\text { Schedule international guest speakers } \\
\text { Reference international case studies }\end{array}$ & $19 \%$ & $81 \%$ \\
$\begin{array}{l}\text { Challenges students to explore cross- } \\
\text { cultural perspectives within their } \\
\text { discipline }\end{array}$ & $66 \%$ & $34 \%$ \\
$\begin{array}{l}\text { Employ technology based solutions to } \\
\text { ensure equal access to }\end{array}$ & $13 \%$ & $60 \%$ \\
$\begin{array}{l}\text { internationalisation opportunities } \\
\text { for all students }\end{array}$ & & $87 \%$ \\
$\begin{array}{l}\text { Use publically available IoC guides to } \\
\text { inform your teaching }\end{array}$ & $7 \%$ & $93 \%$ \\
\hline
\end{tabular}


questionnaire, see Table 3, and the mean levels of lecturers' engagement with and understanding of IoC as measured by questionnaire data.

There was no statistical difference between males and females' interpretation of their understanding of what IoC is $(p=0.573)$, their interpretation of their engagement with $\operatorname{IoC}(p=0.099)$, their interpretation of support for $\operatorname{IoC}(p=0.930)$ or their interpretation of obstacles in IoC $(p=0.320)$.

Regarding age, years' teaching experience and disciplinary backgrounds of the respondents, one-way ANOVA tests were conducted to test for statistically significant associations between the qualitative variables. There was no statistical difference between the age categories and the overall understanding of $\mathrm{IoC}(p=0.689)$ and engagement with IoC $(p=0.7)$.

With respect to years teaching, a statistically significant difference was found between years' teaching and lecturers' levels of understanding of IoC $(p=0.024)$. Furthermore there was a statistically significant difference found between lecturers who have $0-1$ years' experience against $10+$ years' experience and their interpretation of engagement with IoC $(p=0.045)$. Lecturers with $10+$ years' experience reported having a greater understanding and being more engaged with IoC.

Regarding disciplinary background, the tests revealed that there was a statistical difference between lecturers who teach Science and Arts \& Humanities disciplines, interpretation of their engagement with IoC $(p=0.008)$. More specifically, lecturers on Arts \& Humanities programmes expressed a greater understanding and engagement with IoC compared with lecturers from Science disciplines. Table 11 further details the disciplinary differences regarding lecturers' engagement with IoC as per questions that yielded a statistically significant difference.

\section{Discussion of findings}

Existing literature on IoC attributes staff engagement, or lack thereof, as the key impediment to its successful implementation. The literature extensively documents the role of lecturers' engagement in the successful implementation of IoC (Clifford and Montgomery 2011; Hudzik 2015a, 2015b; Kahn and Agnew 2015; Leask 2001, 2007; Whitsed and Green 2016), yet there is a shortage of studies that discuss how to engage lecturers with the process. There is a need for more literature that focusses on examining lecturers' engagement with IoC from their own perspective, in particular in the Irish higher education context (Clarke, Yang, and Harmon 2018; Clifford and Montgomery 2011; Dunne 2009; Green and Whitsed 2015; O’ Reilly, Hickey, and Ryan 2013). This study aimed to understand the perceived theory/practice implementation gap through attaining a comprehensive insight into the level of understanding of and engagement with the process from the lecturers' perspective. The findings from this research did provide some answers to both research questions:

(1) To what extent do lecturers understand and engage with the concept of Internationalisation of the Curriculum?

(2) If lecturers are not engaging with IoC, why is this the case in spite of an increasing presence of internationalisation in Government, HEI and HEA policy documents and an increasing number of Internationalisation of the Curriculum guides? 
Table 11. Statistically significant findings from disciplinary background Anova tests.

\begin{tabular}{|c|c|c|}
\hline Questionnaire question & Discipline comparison & $\begin{array}{c}P- \\
\text { value }\end{array}$ \\
\hline \multirow[t]{3}{*}{$\begin{array}{l}\text { Q.8: In your experience, how often is } \\
\text { information about IoC communicated } \\
\text { to academics? }\end{array}$} & $\begin{array}{l}\text { Arts \& Humanities lecturers reported } \\
\text { receiving more communication re IoC } \\
\text { than Science lecturers }\end{array}$ & 0.030 \\
\hline & $\begin{array}{l}\text { Engineering lecturers reported receiving } \\
\text { more communication re IoC than } \\
\text { Science lecturers }\end{array}$ & 0.022 \\
\hline & $\begin{array}{l}\text { Arts \& Humanities modules had more } \\
\text { internationally focussed modules than } \\
\text { science modules }\end{array}$ & 0.034 \\
\hline \multirow{3}{*}{$\begin{array}{l}\text { Q.14: In the modules which you deliver, to } \\
\text { what extent do assessment tasks require } \\
\text { students to consider issues from a variety } \\
\text { of cultural perspectives? }\end{array}$} & $\begin{array}{l}\text { Business assessments required this more } \\
\text { than Science assessments }\end{array}$ & 0.022 \\
\hline & $\begin{array}{l}\text { Arts \& Humanities assessments required } \\
\text { this more than Engineering }\end{array}$ & 0.013 \\
\hline & $\begin{array}{l}\text { Arts \& Humanities assessments required } \\
\text { this more than Science }\end{array}$ & 0.000 \\
\hline $\begin{array}{l}\text { Q.19: Do you integrate international or } \\
\text { cross-cultural perspectives within your } \\
\text { teaching to internationalise your } \\
\text { curriculum? }\end{array}$ & $\begin{array}{l}\text { Arts \& Humanities lecturers' reported } \\
\text { doing this more than Science lecturers }\end{array}$ & 0.016 \\
\hline \multirow{2}{*}{$\begin{array}{l}\text { Q.19: Do you challenge students to explore } \\
\text { cross-cultural perspectives within your } \\
\text { discipline to internationalise your } \\
\text { curriculum? }\end{array}$} & $\begin{array}{l}\text { Business lecturers reported doing this } \\
\text { more than Science lecturers }\end{array}$ & 0.023 \\
\hline & $\begin{array}{l}\text { Arts \& Humanities lecturers reported } \\
\text { doing this more than Science lecturers }\end{array}$ & 0.000 \\
\hline
\end{tabular}

The following sections discuss the findings that address these research questions.

\section{Lecturers' understanding \& engagement with the concept of internationalisation of the curriculum}

Upon examining the findings relating to research question 1, it emerged that lecturers in the sample surveyed are at the early stage of the internationalisation process in their T\&L environments. Analysis of the questionnaire responses show that lecturers typically do recognise the value and opportunities associated with internationalisation of higher education, however, the general understanding is quite a narrow level conceptualisation and does not typically recognise the educational benefits. More specifically the most common modal response when lecturers were asked to describe internationalisation of higher education was 'culture and diversity'. Furthermore, when asked about IoC in particular, some of the lecturers' responses in this study revealed that they had an awareness of the fact cultural diversity exists in their classrooms and an understanding of the need to incorporate international dimensions into the curriculum. According to the literature, this is in line with what the IoC process intends to achieve, which is leveraging on the culture diversity and utilising it as a transformative teaching resource (Clifford 2009; De Wit \& Leask, cited in Whitsed and Green 2015; Dunne 2011; Haigh 2002, 2014; Kahn and Agnew 2015; Van Gyn et al. 2009). Many 
lecturers also associated the role of IoC in improving the employability of graduates. Their association of IoC with graduate attributes implies their understanding of the relevance of $\mathrm{IoC}$ for all students, not just the international cohort. Therefore some of the lecturers engaged in this research are associating IoC with what it intends to do and this is the first step in achieving IoC. Many lecturers attributed their engagement with internationalisation to their own professional and personal international experiences. However, in terms of engagement, most lecturers reported being somewhat engaged with IoC and many reported seldom or never addressing IoC in their T\&L. While there is an awareness and appreciation of the potential of IoC, the implementation gap still exists which is consistent with international literature on the subject (Daniels 2013; Hudzik and McCarthy 2012; Van Gyn et al. 2009).

In addition to this, the fact that most of the remaining emerging themes were primarily associated with international students, mobility and corresponding financial gains of internationalisation would suggest that lecturers' overall conceptualisation is narrow. The student-centred educational benefits and more comprehensive, twoway understanding of internationalisation of higher education was not typically recognised (Beelen and Jones 2015; De Wit \& Leask 2015; Hudzik and McCarthy 2012; Svensson and Wihlborg 2010). Furthermore the negative connotations associated with marketisation of higher education as a result of globalisation were to the fore. The findings suggest that while an awareness, understanding and interest in IoC does exist amongst the sample surveyed, institutions need to foster this interest through providing the necessary supports and facilitating an environment for lecturers to engage with IoC. This further supports the argument that there is a lack of clear vision, communication and CPD support for the concept and practice of IoC which is necessary in order to support lecturers in this regard (Clifford 2009; Whitsed and Green 2016).

This is in keeping with international literature which associates IoC implementation difficulties with the fact that HEIs tend to focus primarily on mobility and the economic benefits of internationalisation, rather than the educational gains (Clifford 2009; Foster et al. 2013; Harris 2011; Montgomery 2010). The institution's stance on internationalisation therefore impacts on lecturers' conceptualisation and subsequent engagement. If recruitment and mobility are solely prioritised, IoC is likely to be underdeveloped. This emphasises the importance of the institution's internationalisation policy reflecting and supporting engagement with internationalisation at a T\&L level and promoting its relevance to the whole student cohort.

The findings generated in this research are also broadly in line with a recently published Higher Education Authority (HEA) report on the Internationalisation of Irish Higher Education (Clarke, Yang, and Harmon 2018) which stated that the majority of lecturers in Irish HEIs are at the early stages of the internationalisation process in their T\&L environments and were not familiar with the term IoC. The report also acknowledged that more needs to be achieved in the area of IoC to prepare graduates for the global working environment. This confirms the findings of this study were representative of lecturers across Irish HEIs. Furthermore this study extends the work of this HEA report (2018) by specifically providing a snapshot of lecturers' understanding and engagement with IoC in the Irish HE context. It also offers a situational analysis tool for other Irish HEIs to adopt and utilise in order to address and reform the inherent implementation gap between the theory and practice of internationalisation in their institutions. 


\section{Key reasons for lecturers limited engagement with internationalisation of the curriculum}

While some of the educational benefits of internationalisation were reported and recognised, findings from this study suggest that a perceived lack of institution support limits this understanding and also contributes to a negative attitude to the process. Time constraints and conflicting T\&L priorities were also cited as an impediment to successful implementation which is consistent with the literature (Crosling et al. 2008; Hudzik 2015a, 2015b).

It is also clear from the findings of this study that student-centred teaching activities such as IoC, which are the stated T\&L objectives of HE institutions, demand more sophisticated planning of lessons and associated time. Also the statistically significant difference found between years teaching and engagement with $\mathrm{IoC}$ is to be expected as IoC is essentially best practice teaching, which typically develops with experience. It is, however, worth noting that the majority of respondents had 10+ years teaching experience and in spite of this, overall engagement with IoC was typically low. This again emphasises the fact that IoC is a specific T\&L approach and lecturers need CPD to understand the concept and practice (Dunne 2011; Green and Whitsed 2015; Leask 2013; Van Gyn et al. 2009). Clifford (2002) highlights the lack of support provided by HEIs to prioritise their rhetoric of focussing on best practice teaching. Similarly Hughes and Munro (2018) remark that the curriculum in Irish higher education is not explicitly discussed in policy documents, however the university programme expectations and outcomes are (Hughes \& Munro cited in Clarke, Yang, and Harmon 2018). The concepts of IoC have currency beyond international education as they support best practice teaching in general in HEIs (Williams 2008; Van Gyn et al. 2009). More broadly, increased implementation of successful IoC T\&L strategies will help students develop their sense of being an ethical, global citizen, and the skills of being interculturally competent, emotionally intelligent, an active team player, an excellent communicator and a collaborative worker, all of which are important graduate attributes and significant for all students.

There is a direct correlation between internationalisation of HEIs and the employability skills of graduates (De Wit and Jones 2014; Jones 2011; Jones 2013). Furthermore Jones (2013) argues that all students should have an international experience as part of their education. Hence, IoC policy should be situated within the overarching T\&L enhancement agenda of HEIs in order to engage lecturers with its role in inspiring more innovative T\&L approaches (De Wit 2010; HEA 2012; Leask 2011, 2015) and reinforcing the institution's graduate attributes (De Wit and Jones 2014; Jones 2011; Jones 2013).

The findings from the statistical tests within this research study regarding lecturers who teach science/ engineering and arts \& humanities/ business disciplines interpretation of engagement with $\mathrm{IoC}$, are consistent with the literature which states that lecturers of hard disciplines tend to be less open to $\mathrm{IoC}$ then lecturers in more softer or applied disciplines (Bell 2004; Clifford 2009). The literature reports that lecturers of hard disciplines tend to be more focussed on the content rather than the broader academic development of students (Clifford 2009). The tests in this study also revealed that science and engineering lecturers received less communication regarding IoC than the arts $\&$ humanities lecturers which could be a contributing factor to this difference in engagement. 
In Technological Universities, as per this research study, international student numbers are typically much higher in engineering and science disciplines than in arts $\&$ humanities. This suggests that while lecturers of hard disciplines are more exposed to international students in their T\&L contexts, they are still not typically engaging with $\mathrm{IoC}$ as it is not part of their typical teaching culture. IoC demands that lecturers look beyond the curriculum content and focus more on the personal and academic development of students. This approach does not typically come naturally to lecturers and they need to be supported in this regard (Bell 2004; Clifford 2009). The next phase of this research aims to develop a cross-disciplinary space to support lecturers to implement $\mathrm{IoC}$ through highlighting the fact that best practice IoC predominantly transcends disciplinary context. While the contextual nature of IoC results in disciplinary differences in its implementation, the concepts and practice of IoC align with accepted best practice in $\mathrm{T} \& \mathrm{~L}$ and hence bare relevance to all disciplines.

This study's findings also indicate that institution's international strategies and/ or the educational benefits of IoC are not being adequately communicated through senior leadership or other channels of communication. There is a lack of CPD opportunities regarding the specific IoC challenges that lecturers reported on such as engaging with cultural diversity in class, organising cross-cultural groups and developing intercultural competencies. There is also a lack of awareness concerning publically available IoC guides. As a result the majority of lecturers amongst the sample surveyed are not engaging with IoC strategies in their lecture delivery as they are not sure what is involved at a practical level.

In essence any lack of understanding or negativity associated with IoC found within this research appears to stem from the perceived lack of support and in turn a lack of knowledge of the educational benefits of internationalisation. This is consistent with the findings of other IoC studies which typically attribute the lack of engagement with internationalisation to lack of awareness/interest due to lack of CPD and institutional support (Childress 2010; Dunne 2011; Green and Whitsed 2015; Kahn and Agnew 2015; Leask 2013; Van Gyn et al. 2009).

\section{Recommendations for policy and practice}

The recommendations for policy and practice have been categorised as follows and are subsequently discussed.

- HEIs to conduct situational analysis of IoC

- Lecturers' perspectives should be central to IoC policy \& practice

- Successful IoC implementation demands a relevant support framework

- IoC CPD should reflect the T\&L practicalities of internationalisation

\section{HEIs to conduct situational analysis of IoC}

This study's findings highlight the benefits of conducting a situational analysis to further understand engagement with IoC from the perspective of the lecturers, who should be the key proponents to realise any type of curriculum change. As Irish HEIs are developing more comprehensive strategies to address internationalisation it is recommended that similar situational analysis activities are conducted in other Irish HEIs and responses incorporated and addressed in the institution's policy documents. This should be the first step in the institution's IoC process. 


\section{Lecturers' perspectives should be central to IoC policy \& practice}

IoC is a critical component of an institution's internationalisation strategy, and more broadly speaking the institution's overall T\&L enhancement agenda. Lecturers are central to this and should be included in the T\&L enhancement process (Green and Whitsed 2015; Hudzik 2015a, 2015b; Leask 2013). Based on these findings it is recommended that internationalisation of higher education strategy documents should be more focussed on the practical implementation of the strategy in the T\&L environment which in turn should be informed by the lecturers' perspectives (Clifford and Montgomery 2011; Green and Whitsed 2015; O' Reilly, Hickey, and Ryan 2013). IoC policy and practice needs to reflect this and should be informed by lecturers' needs and perspectives. As previously mentioned lecturers have not typically been central to IoC discussions and research to date (Leask 2013; Clifford and Montgomery 2011; Green and Whitsed 2015). Similarly and more broadly speaking the lack of attention given to T\&L research and support for lecturers is echoed in the literature (Robson, Wall, and Lofthouse 2013). This is a significant issue and the key contributing factor to theory practice implementation gaps. This study demonstrated the disconnect between the theory and practice of internationalisation of higher education and is contributing to this gap by ascertaining the lecturers' perspectives and by explaining the implementation gap in terms of their everyday practice. It extends the work of Clarke, Yang, and Harmon (2018) by specifically focussing on lecturers' perspectives of IoC and by subsequently recommending that these perspectives inform policy and practice.

\section{Successful IoC implementation demands a relevant support framework}

An institution's IoC support framework should include senior leadership support, funding and resources (Haigh 2002; Childress 2010; Hudzik 2015a). While institutional strategies may communicate a mission statement that speaks of a more comprehensive approach to internationalisation, this study showed that lecturers do not feel they have either the time or support to achieve this. Based on the feedback from the questionnaire, it is recommended that lecturers are incentivised to engage with IoC through some form of time release. It was clear that the main deterrents were associated with lack of support and lack of time. Both of which should be addressed in the associated policy documents to ensure the practicalities are realised. Lecturers cannot be expected to modernise and amend their T\&L strategies, for example through the implementation of IoC, if they do not have sufficient time and support to do so. HEI need to recognise lecturers' concerns regarding interalia workload, conflicting priorities and non-recognition of time required, when promoting internationalisation internally within their organisations. In line with the HEA report on internationalisation of HE (Clarke, Yang, and Harmon 2018) the findings of this study underline the need for improved clarity surrounding the rationale and future direction of internationalisation and specifically IoC within Irish HEIs.

\section{Ioc CPD should reflect the $T \& L$ practicalities of internationalisation}

Regarding CPD for IoC, the supports available to lecturers must align with the institution's overall T\&L enhancement agenda. T\&L is one of the core missions of HEIs and demands a support structure in order for best practice and, the institution's T\&L 
philosophy to be realised. This highlights the need for appropriate CPD, which further justifies the rationale for this project to trial an IoC: $\mathrm{CoP}$ to try to enhance engagement with IoC, this will be further discussed in phase two of this research. IoC is an area that demands further consideration in the Irish context. It is also recommended that the National Forum for Teaching and Learning provides support for HEIs in this regard.

\section{Future work}

Phase two of this research aims to respond to some of the concerns raised by lecturers through their questionnaire responses. This will be addressed by establishing a crossdisciplinary IoC: CoP to support lecturers to further incorporate IoC into their T\&L environments. The CoP aims to facilitate an environment whereby lecturers can critically reflect on their current practice and collegially interact to explore how they can add international and intercultural dimensions into their delivery regardless of their disciplinary background.

The critical objective is for the CoP to influence a culture of support for IoC and increase the implementation of IoC strategies in the T\&L environment thereby enhancing the T\&L delivery. This in turn will respond to the gap in the literature in relation to the need to further acknowledge lecturers' perspectives on IoC and provide meaningful CPD to further support them. The CoP will be set up to trial a methodology of engaging lecturers and the findings will be reported in phase two.

\section{Supplemental data}

Supplemental data for this article can be accessed doi:10.1080/ 03323315.2019.1663551

\section{Notes on contributors}

Deirdre Ryan has been working in international higher education for the past thirteen years following the completion of her BSc in Computer Systems in 2002 and her Masters in English Language Teaching in 2005 in the University of Limerick, Ireland. She is Coordinator of the International Pathway Programmes in Technological University Dublin. Previously she taught TEFL and was Director of Studies in Monash University English Language Centre in Melbourne for eight years. She is currently pursuing her PhD research in the field of Internationalisation of the Curriculum and lecturer's engagement with the process.

Fiona Faulkner is a mathematics lecturer on a foundation programme for adult and international students in Technological University Dublin. She is a qualified secondary school mathematics and Physical Education teacher (BSc 2004-2008) with a PhD in mathematics education (2008-2012) both from the University of Limerick, Ireland. While completing her doctoral studies she lectured on adult education mathematics and statistics programmes as well as mathematics undergraduate modules. She has worked as the Academic Co-ordinator and a lecturer on the Professional Diploma in Mathematics for Teaching (2012-2014) in the University of Limerick. She is also a research associate of the EPI-STEM (National Centre for STEM education in Ireland) which is also based in the University of Limerick. Her current research interests lie in the areas of mathematics diagnostic testing, out of field teaching, mathematics education for access and international students and teaching mathematics for understanding.

Dominic Dillane is Head of School of Hospitality, Management \& Tourism in Technological University Dublin. He has a BSc Degree in Actuarial Science from the University of Kent, Canterbury, an MSc in Statistics from University College Dublin (UCD) and a PhD in Statistics 
from Trinity College Dublin (TCD). His current research interests include mathematical statistics, tourism market research techniques and higher education

Robert Flood is Head of International Affairs in Technological University Dublin. He holds a BSc and PhD in Chemistry from University College Dublin, an MPhil in Physical Chemistry from the University of Edinburgh and a DBS from the Irish Management Institute. He has worked for over a decade in international education in his current role. He is a Ministerial appointee to the High Level Group on International Education and is a co-author on two government strategies for international education in Ireland. He is also a member of the Dublin City Council International Advisory Board providing guidance and advice in particular on education. His research interest in the field of education include Internationalisation of the Curriculum and the economic impact of international education on cities and regions.

\section{References}

American Council on Education. 2012. "Mapping Internationalisation on US Campuses." Accessed March 5, 2015. https://www.acenet.edu/news-room/Pages/MappingInternationalization-on-U-S-Campuses.aspx.

Beelen, J., and E. Jones. 2015. "Europe Calling: A New Definition for Internationalisation at Home." International Higher Education Special 83: 12-13.

Bell, M. 2004. "Internationalising the Higher Education Curriculum: Do Academics Agree?" Proceedings of the 27th Higher Education Research \& Development Society of Australasia (HERDSA) Conference, Miri, Sarawak.

Bergerhoff, J., L. Borghans, P. K. Seegers, and T. Van Veen. 2013. International Education and Economic Growth. Accessed January 10, 2016. http://ftp.iza.org/dp7354.pdf.

Bethlehem, J. 2008. "How Accurate are Self-Selection Web Surveys?" Accessed April 20, 2016. https://peilingpraktijken.nl/wp-content/uploads/2014/06/bethlehem04.pdf.

Childress, L. K. 2010. The Twenty-First Century University: Developing Faculty Engagement In Internationalization. New York: Peter Lang.

Clarke, M., L. Yang, and D. Harmon. 2018. "The Internationalisation of Irish Higher Education." Higher Education Authority.

Clifford, V. 2002. "Provoking Change: A Feminist, Collaborative Process of Academic Development." In Gender, Teaching and Research in Higher Education Challenges for the Twenty-first Century, edited by G. Howie, and A. Tauchert, 222-236. Aldershot, Hants: Ashgate Pub Ltd.

Clifford, V. 2009. "Engaging the Disciplines in Internationalising the Curriculum." International Journal for Academic Development 14 (2): 133-143.

Clifford, V., and C. Montgomery. 2011. "Ch 1 Introduction: Internationalizing the Curriculum for Global Citizenship in Higher Education." In Moving Towards Internationalisation of the Curriculum for Global Citizenship in Higher Education, edited by V. Clifford and C. Montgomery, 13-24. Oxford, UK: OCSLD, Oxford Brookes University.

Coate, K. 2013. An Ethical Commitment: Responsibility, Cosmopolitanism and Care in the Internationalised University. Accessed July 6, 2016. https://aran.library.nuigalway.ie/xmlui/ bitstream/handle/10379/2967/CoateRathnayake2012.pdf?sequence $=1$.

Coelen, R. 2015. "Why Internationalize Education." International Higher Education 85: 4-5. doi:10.6017/ihe.2015.83.9074.

Cohen, L., L. Manion, and K. Morrsion, eds. 2007. Research Methods in Education. 6th ed. London: Routledge.

Creswell, J. W. 2003. Research Design: Qualitative, Quantitative and Mixed Methods Approaches, (2nd ed.). Thousand Oaks: Sage.

Crosling, G., R. Edwards, and B. Schroder. 2008. "Internationalizing the Curriculum: The Implementation Experience in a Faculty of Business and Economics." Journal of Higher Education Policy and Management 30 (2): 107-121.

Daniels, J. 2013. “'Internationalisation, Higher Education and Eduators' Perceptions of Their Practices'." Teaching in Higher Education 18 (3): 236-248.

Department of Education and Skills. 2010. "Investing in Global Relationships: Ireland's International Education Strategy 2010-15." Accessed February 5, 2015. https://www. 
education.ie/en/Publications/Policy-Reports/Ireland-s-International-Education-Strategy2010-2015-Investing-in-Global-Relationships.pdf.

Department of Education and Skills. 2016. "Irish Educated Globally Connected. An International Education Strategy for Ireland." Accessed March 20, 2016. https://www. education.ie/en/Publications/Policy-Reports/International-Education-Strategy-For-Ireland2016-2020.pdf.

De Wit, H. 2010. "Internationalisation of Higher Education in Europe and its Assessment." Accessed March 20, 2015. https://educ.utm.my/sanitah/files/2016/02/Internationalisation_ of_Higher_Education_in_Europe_DEF_december_2010.pdf.

De Wit, H., F. Hunter, L. Howard, and E. Egron-Polak. 2015. "Internationalisation of Higher Education Study." Accessed March 20, 2015. http://www.europarl.europa.eu/RegData/ etudes/STUD/2015/540370/IPOL_STU(2015)540370_EN.pdf.

De Wit, H., and E. Jones. 2014. We Need to Change the Language of Internationalisation.” University World News, November 14, 2014, Issue No. 343.

Dunne, C. 2009. "'Host Students' Perspectives of Intercultural Contact in an Irish University"." Journal of Studies in International Education 13 (2): 222-239. Accessed July 13, 2016. http:// journals.sagepub.com/doi/abs/10.1177/1028315308329787.

Dunne, C. 2011. "Developing an Intercultural Curriculum within the Context of the Internationalisation of Higher Education: Terminology, Typologies and Power." Higher Education Research \& Development 30 (5): 609-622.

Egron-Polak, E., and R. Hudson. 2014. Internationalisation of Higher Education: Growing Expectations, Fundamental Values." IAU 4th Global Survey. Accessed March 7, 2015. http://www.iau-aiu.net/sites/all/files/IAU-4th-GLOBAL-SURVEY-EXECUTIVESUMMARY.pdf.

European Association for International Education. 2014. "Revealing the state of internationalisation in Europe: the EAIE Barometer results are out." Accessed February 6, 2016. http:// www.eaie.org/blog/revealing-the-state-of-internationalisation-in-europe-the-eaie-barometerresults-are-out/.

Finn, M., and M. Darmody. 2017. "What Predicts International Higher Education Students Satisfaction with Their Study in Ireland." Journal of Further and Higher Education 41 (4): 545-555. Accessed October 22, 2015. http://www.tandfonline.com /doi/full/10.1080/ 0309877X.2015.1135887.

Foster, K., Y. Yao, D. Buchanan-Butterfield, and A. Powell-Brown. 2013. "Spreading Our Wings: International Education as Journeys of Enriched Learning." Multicultural Perspectives 15 (3): 168-173.

Fowler, F. J. 2014. Survey Research Methods. 5th ed. California, USA: Boston Sage Publications Inc, Centre for Survey Research, University of Massachusetts.

Green, W., and C. Whitsed. 2015. "Introducing Critical Perspectives on Internationalising the Curriculum." In Critical Perspectives on Internationalising the Curriculum in Disciplines, edited by W. Green and C. Whitsed, 3-23. The Netherlands: Sense Publishers.

Haigh, M. J. 2002. "Internationalisation of the Curriculum: Designing Inclusive Education for a Small World." Journal of Geography in Higher Education 26 (1): 49-66. Accessed January 20, 2016. Available from Ebsco Host.

Haigh, M. J. 2014. "From Internationalisation to Education for Global Citizenship: a MultiLayered History." Higher Education Quarterly 68 (1): 6-27.

Harris, S. 2011. The University in Translation: Internationalizing Higher Education. London: Bloomsbury Publishing PLC.

Hawanini, G. 2011. "The Internationalisation of Higher Education Institutions: A Critical Review and a Radical Proposal." Accessed February 20, 2016. https://sites.insead.edu/ facultyresearch/research/doc.cfm?did $=48726$.

Hegarty, N. 2014. "Where Are We Now - The Presence and Importance of International Students to Universities in the United States." Accessed February 10, 2016. https://books. google.ie/books?hl=en\&lr=\&id=Dui4CgAAQBAJ\&oi=fnd\&pg=PA223\&dq=hegarty

+ internationalisation+economic + us\&ots $=$ UECCAzG4MR\&sig $=$

PE1WUY11LiAEEtuEZowUonV0OLc\&redir_esc $=\mathrm{y} \# \mathrm{v}=$ onepage \&q \&f=false. 
Hellsten, M. 2007. "International Student Transition: Focusing on Researching International Pedagogy for Educational Sustainability." International Education Journal: Comparative Perspectives 8 (3): 79-90.

Henard, F., L. Diamond, and D. Roseveare. 2012. "Approaches to Internationalisation and Their Implications for Strategic Management and Institutional Practice." Accessed February 12, 2015. http://www.oecd.org/education/imhe/Approaches $\% 20$ to $\%$ 20internationalisation $\% 20-\% 20$ final $\% 20-\% 20$ web.pdf.

Higher Education Authority (HEA). 2012. Towards a Future in Higher Education Landscape. Accessed March 5, 2017. http://9thlevel.ie/wp-content/uploads/TowardsaFutureHigher EducationLandscape.pdf.

Higher Education Authority (HEA). 2016. "Dublin Institute of Technology Profile 2016/2017." Accessed June 20, 2016. http://hea.ie/assets/uploads/2017/04/DIT-Profile-2016.pdf, http:// hea.ie/assets/uploads/2017/04/ITB-Profile-2016.pdf.

Hudzik, J. K. 2015a. "Integrating Institutional Policies and Leadership for Twenty-first Century Internationalisation." International Higher Education Special Edition 83: 5-7.

Hudzik, J. K. 2015b. "Strategic Institutional Partnerships and Comprehensive Internationalisation." In Higher Education Partnerships for the Future, edited by N. Jooste, H. De Wit, and S. Heleto, 23-39. Accessed January 10, 2016. http://obiret-iesalc.udg.mx/ sites/default/files/publicaciones/9._higher_education_partnerships_for_the_future. pdf\#page $=23$.

Hudzik, J. K., and J. S. McCarthy. 2012. "Leading Comprehensive Internationalisation: Strategy and Tactics for Action." Accessed March 13, 2015. http://www.nafsa.org/ uploadedFiles/Chez_NAFSA/Resource_Library_Assets/Publications_Library/Leading\% 20CIZN.pdf.

Hunt, C. 2011. "National Strategy for Higher Education to 2030." Accessed February 5, 2015. http://hea.ie/assets/uploads/2017/06/National-Strategy-for-Higher-Education-2030.pdf.

Indicators for Mapping and Profiling Internationalisation (2009-2012). Accessed June 20, 2015. https://www.up2europe.eu/european/projects/indicators-for-mapping-and-profilinginternationalisation_119130.html.

Jones, E., ed. 2010. Internationalisation and the Student Voice Higher Education Perspectives. New York: Routledge.

Jones, E. 2011. "Internationalisation, Multiculturalism, A Global Outlook and Employability." Accessed July 6, 2016. http://eprints.leedsbeckett.ac.uk/1194/1/ Internationalisation $\% 2 \mathrm{C} \%$ 20multiculturalism $\% 2 \mathrm{C} \% 20 \mathrm{a} \% 20$ global $\% 20$ outlook $\% 20$ and $\% 20$ employability1.pdf.

Jones, E. 2013. "Internationalization and Employability: The Role of Intercultural Experiences in the Development of Transferable Skills." Accessed July 8, 2016. http://www.academia.edu/ 2489954/Internationalization_and_employability_the_role_of_intercultural_experiences_in_ the_development_of_transferable_skills.

Kahn, H. E., and M. Agnew. 2015. "Considerations for Teaching, Learning and the Internationalization of Higher Education." Journal of Studies in International Education 21 (1): 52-64.

Kreber, C. 2009. "Different Perspectives on Internationalisation in Higher Education." Accessed February 8, 2016. https://www.researchgate.net/profile/Carolin_Kreber/ publication/

247989946_Different_perspectives_on_internationalization_in_higher_education/links/ 55f7767608aeafc8ac015511.pdf.

Leask, B. 2001. "Bridging the Gap: Internationalizing University Curricula." Journal of Studies in International Education 5 (2): 100-115.

Leask, B. 2007. "Diversity on Campus - An Institutional Approach: A Case Study from Australia, Internationalisation at Home: Ideas and Ideals.” EAIE Occasional Paper 20, European Association for Internationalisation Education (EAIE), p. 133.

Leask, B. 2009. "Using Formal and Informal Curricula to Improve Interactions between Home and International Students." Accessed January 15, 2016. http://site.valenciacollege.edu/inz/ library/INZ $\% 20$ the $\% 20$ urriculum/Using $\% 20$ Formal $\% 20$ and $\% 20$ Informal $\% 20$ Curricula $\%$ 20 to $\% 20$ Improve $\% 20$ Interactions $\% 20$ Between $\% 20$ int $1 \% 20$ and $\% 20$ domestic $\% 20$ students $\%$ 20(Leask).pdf. 
Leask, B. 2011. "Assessment, Learning, Teaching and Internationalisation - Engaging for the Future." Accessed August 27, 2015. http://eprints.leedsbeckett.ac.uk/1191/1/ Assessment\% $2 \mathrm{C} \% 20$ learning $\% 2 \mathrm{C} \% 20$ teaching $\% 20$ and $\% 20$ internationalisation.pdf.

Leask, B. 2013. "Internationalizing the Curriculum and Student Learning: Preparing Graduates for the twenty-first Century." Accessed July 11, 2016. http://citeseerx.ist.psu.edu/viewdoc/ download?doi=10.1.1.371.9144\&rep=rep1\&type $=$ pdf.

Leask, B. 2015. Internationalizing the Curriculum Routledge. London: Taylor \& Francis.

McKinnon, K. R., S. H. Walker, and D. Davis. 2000. "Benchmarking a Manual for Australian Universities." Accessed June 20, 2015. http://citeseerx.ist.psu.edu/viewdoc/download?doi= 10.1.1.94.9410\&rep=rep1\&type $=$ pdf.

Montgomery, C. 2010. Universities Into the Twenty-first Century Understanding the International Student Experience. Hampshire, UK: Palgrave MacMillan.

O' Reilly, A., T. Hickey, and D. Ryan. 2013. "'Higher Education Professionals' Perspectives on International Student Experiences of Life and Learning in Ireland: A Qualitative Study'.” Irish Educational Studies 32 (3): 355-375.

Robson, S., K. Wall, and R. Lofthouse. 2013. "Raising the Profile of Innovative Teaching in Higher Education? Reflections on the EQUATE Project." International Journal of Teaching and Learning in Higher Education 25 (1): 92-102.

Svensson, L., and M. Wihlborg. 2010. "Internationalising the Content of Higher Education: The Need for a Curriculum Perspective." Higher Education 60: 595-613. Accessed February 21, 2015. Available from Ebsco Host.

Universities UK. 2014. "International Students in Higher Education: The UK and Its Competition." Accessed February 4, 2016. https://www.universitiesuk.ac.uk/policy-andanalysis/reports/Documents/2014/international-students-in-higher-education.pdf.

Van Gyn, C. Caws, S. Lehr, and A. Preece. 2009. "Education for World-mindedness: Beyond Superficial Notions of Internationalization." New Directions for Teaching and Learning, 118. Accessed February 5, 2017. https://www.researchgate.net/profile/Catherine_Caws/ publication/230409918_Education_for_worldmindedness_Beyond_superficial_notions_of_ internationalization/links /00b4952cdb23ab310f000000.pdf.

Whitsed, C., and W. Green. 2015. "Internationalisation of the Curriculum and the "New Normal”: An Australian Perspective." International Higher Education 83 (2015): 13-15. Accessed August 20, 2016. https://ejournals.bc.edu/ojs/index.php/ihe/article/view/9081/8188.

Whitsed, C., and W. Green. 2016. "Lessons From Star Trek: Engaging Academic Staff in the Internationalisation of the Curriculum." International Journal for Academic Development 21: $1-3$.

Williams, S. 2008. "Internationalization of the Curriculum: A Remedy for Academic Students' Academic Adjustment Difficulties?" Accessed June 8, 2016. http://web.uvic.ca/ sherriw/ images/ED $\% 206890 \% 20$ Sherri $\% 20$ Williams $\% 20$ Final $\% 20$ Paper $\% 20$ for $\% 20$ website.pdf. 